\title{
Expansão da Rede de Telégrafos em Santa Catarina: Sistema Regional de Economia e Adensamento do Estado no Território Catarinense*
}

\section{Expansion of the Telegraph Network in Santa Catarina: Regional System of Economy and State Density in the Territory of Santa Catarina}

Alcides Goularti Filho ${ }^{\mathrm{a}}$

\begin{abstract}
Resumo: O objetivo deste artigo é descrever a expansão da rede de telégrafos em Santa Catarina entre 1866 e 1930 focalizando a análise na formação do sistema regional de economia e no adensamento do Estado no território. Parte-se do pressuposto de que transportes e comunicações são unidades constitutivas do território e estão ligadas diretamente às ações do Estado por meio de múltiplas estratégias e interesses. Além das considerações finais, o texto está dividido em quatro tópicos. O primeiro discute a relação entre território e comunicações destacando aspectos teóricos e metodológicos que norteiam o artigo. O segundo tópico aborda a formação do sistema regional de economia a as comunicações. No tópico seguinte, temos uma trajetória dos telégrafos no mundo e no Brasil e dados abrangentes da Repartição Geral dos Telégrafos. Por fim, o último tema discutido é a trajetória da expansão da rede de telégrafos em Santa Catarina como um dos elementos determinantes na ocupação, definição e construção do território. Esse tópico está subdividido em três períodos: 1866 a 1900 (instalação e início da interiorização); 1900 a 1918 (expansão e integração da rede); e 1918 a 1930 (formação do sistema e novos serviços de comunicações). As considerações finais versam sobre o futuro da telegrafia pós-1930 diante dos avanços tecnológicos da área das comunicações.
\end{abstract}

Palavras-chave: Telégrafo. Território. Estado. História. Economia. Santa Catarina.

\begin{abstract}
The aim of this article is to describe the expansion of the telegraph network in Santa Catarina between 1866 and 1930 focusing on the analysis of the regional economic system and the consolidation of the State in the territory. The assumption is that transport and communications are constitutive units of the territory and are directly linked to the actions of the State through multiple strategies and interests. In addition to the final considerations, the text is divided into four topics. The first discusses the relationship between territory and communications highlighting theoretical and methodological aspects that will guide the article. The second topic addresses the formation

\footnotetext{
* $\quad$ Pesquisa financiada pelo CNPQ e FAPESC

a Universidade do Extremo Sul Catarinense (UNESC), Programa de Pós-graduação em Desenvolvi-
} mento Socioeconômico. Criciúma, Santa Catarina, Brasil.
\end{abstract}


of the regional system of economics to communications. In the next topic, we have a trajectory of the telegraphs in the world and in Brazil and comprehensive data of the General Office of Telegraphs. Finally, the last topic discussed is the trajectory of the expansion of the telegraph network in Santa Catarina as one of the determining factors in the occupation, definition and construction of the territory. This topic is subdivided into three periods: 1866 to 1900 (installation and beginning of interiorization); 1900 to 1918 (network expansion and integration); and 1918 to 1930 (formation of the system and new communications services). The final considerations are about the future of post1930 telegraphy in the face of technological advances in communications.

Keywords: Telegraph. Territory. State. History. Economy. Santa Catarina.

JEL Classification: N76; N96.

\section{Introdução: Território e Comunicações}

Os elementos constitutivos do Estado moderno são governo, povo e território. A combinação de todos esses elementos forma uma nação. Tomando apenas o território como objeto de estudo, temos a seguinte definição: a configuração territorial é dada pelo "[...] o conjunto de objetos existentes sobre eles; objetos naturais ou objetos artificiais [...]” (SANTOS, 2012, p. 83). O território também deve ser pensado como uma instância social ou, a partir de uma categoria weberiana, como uma "esfera da existência". Da mesma forma como observamos a economia e a política no mundo social, temos que observar o território nas suas múltiplas escalas, formas e magnitude. O mundo é, ao mesmo tempo, territorializado, pois o natural e o antinatural circulam e se fixam no concreto, e desterritorializado, porque as coisas viajam no abstrato.

Território é uma totalidade que condensa passado e presente, real e virtual em um mesmo instante. Sua conquista, definição e construção contínua são comandadas, em larga medida, pelo Estado, em um processo de adensamento de suas funções. A ocupação torna-se condição necessária para fazer existir o Estado: a definição delimita a área de atuação do Estado, e a construção contínua ocorre por meio da intervenção estatal, que penetra em todos os poros possíveis do território. A combinação desses três movimentos resulta em um adensamento do Estado no território. Adensar significa marcar presença, ir até o local, conectar partes, estabelecer relações de poder, controlar fixos e fluxos e criar condições para a reprodução da existência do próprio território.

As formas de intervenção do Estado no território se dão por meio da construção de camadas geoeconômicas que se combinam e se sobrepõem. As camadas geoeconômicas são os meios de transportes, as comunicações, a rede de energia, o sistema de abastecimento de água e outros. A combinação dessas camadas 
entre si, circunscritas num território, formam um sistema nacional de economia (LIST, 1986) que atua na esfera da produção e circulação com entrelaçamento de diversas modalidades em operação mútua e contínua. Portanto, território e sistema nacional de economia são determinações que constituem uma unidade na diversidade.

Essa definição, que combina território e sistema nacional de economia, ultrapassa a visão de que ambos são determinados e se ajustam apenas à lógica da reprodução ampliada do capital. Essa unidade é o ponto de partida e o ponto de chegada para entendermos, por exemplo, as estratégias de ocupação militar, a expansão demográfica e a proteção das tradições culturais. Esse é o movimento de adensamento do Estado no território. Em uma perspectiva econômica, o adensamento do Estado no território vem no sentido de solucionar problemas e permitir o livre desenvolvimento das forças produtivas. Porém, ao final de cada intervenção, surgem novos problemas que exigirão no futuro próximo intervenções mais complexas e que resultarão em um maior adensamento. Esse movimento de intervenção que simultaneamente adensa o Estado no território é o ponto de chegada e de partida para entendermos a formação do sistema nacional de economia.

Estudar a expansão da rede de telégrafos em Santa Catarina nos ajuda a compreender como o Estado foi fazendo-se presente nas mais distantes vilas e cidades. A ampliação da rede de telégrafo faz parte de uma totalidade que nos permite ver a ocupação, a definição e a construção contínua do território catarinense. Dentro da formação econômica de Santa Catarina, encontramos elementos estruturantes que adensaram o Estado no território, como a abertura e os melhoramentos: da estrada de Lages, que seguia do litoral em direção ao planalto; da estrada do litoral, que integrava todas as localidades da costa leste catarinense; da estrada da mata, que cortava o planalto serrano e possibilitava trafegar no longo caminho de Viamão a Sorocaba; da estrada de Blumenau a Curitibanos, que integrava, em uma única via, dois mundos diferentes - colonos e tropeiros; da estrada Dona Francisca, que integrava o litoral norte ao planalto; e da estrada de Tubarão, que colocava a histórica cidade de Laguna em contato com Lages. Também merece destaque a construção das ferrovias, como a estrada de ferro São Paulo-Rio Grande (EFSPRG), que cortava todo o meio-oeste catarinense; a estrada de ferro Santa Catarina (EFSC), que integrava as colônias do Vale do Itajaí; e a estrada de ferro Dona Tereza Cristina (EFDTC), a ferrovia do carvão no sul catarinense. Na área de comunicações, o Estado chegou às longínquas comunidades catarinenses por meio da abertura de linhas e agências postais. Em 1839, foi aberta a linha postal entre Desterro, a capital da província, e Lages, no interior do planalto serrano; em 1872, a linha chegou às colônias do Vale do Itajaí; em 1881, à vila de Curitibanos; e, por fim, em 1889, avançou em direção ao oeste, abrindo a linha postal até Campos Novos. 
A criação dessas camadas geoeconômicas - transportes e comunicações estava diretamente relacionada ao movimento de ocupação demográfica - como a fundação de colônias de imigrantes - e ao desempenho econômico da pequena produção mercantil e das atividades pecuarista (planalto serrano) e extrativista (madeira, erva-mate e carvão) (GOULARTI FILHO, 2007). Escoar a produção de carvão das minas de Lauro Müller, Urussanga e Criciúma exigia a construção e o prolongamento da EFDTC, que ligava as áreas de extração do mineral aos portos de Laguna e Imbituba. Dentro do complexo ervateiro catarinense, a estrada Dona Francisca e o ramal ferroviário da EFSPRG entre São Francisco e Porto União permitiam que a produção da erva-mate - cortada e colhida em Porto União e Canoinhas e beneficiada em Mafra - chegasse até a cidade industrial de Joinville e ao porto de São Francisco (GOULARTI FILHO, 2013). O mesmo podemos pensar em relação à abertura da linha postal entre Desterro e Lages em 1839, que atendia as solicitações dos latifundiários e aumentava a presença do estado catarinense no planalto serrano, onde a demarcação do território ainda estava indefinida. Em direção ao oeste, em 1889, a linha postal entre Lages e Curitibanos foi estendida até Campos Novos com o objetivo de se chegar mais próximo da fronteira com a Argentina, que naquele momento reivindicava parte do território brasileiro.

Nesse movimento de expansão e definição do território nacional em direção à fronteira oeste com a Argentina, o Decreto $\mathrm{n}^{\circ} 2.502$, de 16 de novembro de 1859, autorizou a criação de duas colônias militares entre os rios Chapecó e Chopim. Devido aos acirramentos em torno da disputa territorial com a Argentina, em 14 de março de 1882 foi fundada a Colônia Militar de Chapecó, que, em menos de uma década, já tinha a estrutura mínima de uma pequena cidade (CABRAL, 1994). Era o Estado adensando-se no extremo oeste catarinense construindo camadas geoeconômicas. Em um primeiro momento, apenas instalou a colônia, em seguida vieram as demandas econômicas e sociais, que exigiam uma maior presença estatal no território.

A constituição da rede telegráfica se deu concomitante com a expansão do sistema de transporte e das linhas postais no Brasil e em Santa Catarina. Partimos do pressuposto de que o sistema nacional de economia está territorializado e o grau de desenvolvimento das forças produtivas, sobretudo a técnica e a financeira, em última instância é que determina o ritmo de acumulação no sistema de comunicação. No Brasil, da segunda metade do século XIX até 1930, a ausência de formas avançadas de organização capitalista retardou o desenvolvimento de uma economia mais organizada (CARDOSO DE MELLO, 1988). Porém, esses entraves não impediram que o país construísse um sistema nacional nos moldes das economias capitalistas centrais. O mesmo podemos pensar em relação a Santa Catarina na comparação com outros estados brasileiros mais avançados. O ritmo lento de acumulação da economia catarinense não foi um entrave que impediu avanços 
materiais consideráveis da sua estrutura produtiva. Podemos afirmar que, durante todo o século XIX e no início do XX, formou-se um mercado interno e um sistema regional de economia, composto de camadas geoeconômicas que adensou o estado no território catarinense.

\section{Sistema Regional de Economia e Comunicações}

Nos estudos sobre formação do sistema nacional de economia e territorialidade, há uma predominância de pesquisas que apresentam o transporte como elemento unificador do território. Ao mesmo tempo que o ritmo de expansão e retração do sistema de transportes é determinado pelo desenvolvimento das forças produtivas, também deve ser entendido como indutor do processo de acumulação. Transportes e produção formam uma totalidade dentro do modo de produção capitalista em que o desempenho de um está associado ao desempenho do outro.

Contudo, temos de entender que a mesma centralidade que assume o transporte na formação do sistema nacional de economia e da construção do território também pode ser pensada para os meios de comunicação, que, no século XIX, eram representados pelos correios e telégrafos. Se o território se estratifica em múltiplas escalas (BRANDÃO, 2007) - local, regional, nacional e internacional -, o sistema de economia que constrói a sua unidade também pode ser observado em escalas diferenciadas. Desse modo, com base em Georg List (1986), é possível pensarmos um sistema regional de economia no qual as diversas camadas geoeconômicas se interligam na escala regional com uma autonomia relativa em relação à esfera nacional.

Ocupar, definir e construir território, acelerar a produção e promover a expansão demográfica são ações que se desenvolvem concomitantemente a partir da disponibilidade de meios de comunicação. A produção e o comércio impulsionam o aperfeiçoamento dos meios de comunicação ao mesmo tempo que os meios de comunicação disponibilizam acesso às informações que são vitais para gerar mais acumulação e ampliar a presença do Estado. Portanto, transporte e comunicação formam uma unidade dentro do movimento geral da acumulação capitalista.

Durante o século XIX, o Brasil se constitui como uma periferia dentro da economia mundial. Nossa herança colonial era reposta cotidianamente pela aristocracia e pela elite nativa, que reforçavam o caráter inorgânico da sociedade e desarticulado da economia. Éramos uma sociedade escravocrata, latifundiária, exportadora de produtos primários tropicais, sem a presença de base produtiva e comercial mais complexa (PRADO JÚNIOR, 1990). Como consequência dessa baixa concentração de capital, ainda no início do século XX tínhamos uma acumulação horizontal, ausentes mecanismos de financiamento e fluxo de renda desigual e distorcido. Mesmo apresentando fragilidades estruturais com um sistema tributá- 
rio débil, a maior capacidade de intervenção e financiamento se concentrava no Estado (FURTADO, 1989).

Como o Brasil ainda não havia internalizado as formas superiores de organização capitalista, o Estado não poderia esmorecer diante do acelerado processo de modernização das forças produtivas que estava em marcha nas economias centrais. Financiar por meio do Tesouro as ferrovias, a navegação, os correios e os telégrafos era criar condições mínimas para formar um sistema nacional e regional de economia. Baixa capacidade de acumulação, fragilidade financeira e insuficiência tributária eram uma causação circular que poderia ser revertida com uma intervenção mais intensa do Estado.

Esse era o padrão de acumulação da economia brasileira durante todo o século XIX e nas primeiras décadas do XX. É dentro desse padrão que temos de entender o desenvolvimento dos telégrafos no Brasil: a dificuldade em melhorar os serviços, o limitado quadro de funcionários e as precárias condições das linhas e das estações. Esses problemas poderiam ser vistos como circunscritos à administração dos telégrafos, mas havia outros que estavam relacionados diretamente ao padrão de acumulação da economia brasileira: as precárias condições das estradas, a ausência da navegação fluvial moderna e o limitado alcance das ferrovias. Com o advento das ferrovias, a situação melhorou, mas o alcance dos telégrafos era limitado pela escassa malha ferroviária. Para realizar a manutenção das linhas e fazer as constantes reposições dos postes e fios, os agentes responsáveis pelos serviços de avarias reclamavam da falta de estradas de boa qualidade. Quando havia estradas em condições de trafegabilidade, era muito comum que as linhas de telégrafos seguissem o mesmo trajeto das estradas ou servisse de acesso à rede de transmissão (REPARTIÇÃO GERAL DOS TELÉGRAFOS, 1866-1880). Portanto, temos de entender as melhorias realizadas no sistema de transportes também como uma demanda advinda dos serviços de telégrafos. A necessidade de acelerar a chegadas das informações tencionava o ministério em realizar melhorias nas estradas. Portanto, transportes e comunicações são partes da mesma totalidade.

\section{Estado e Telégrafos no Brasil}

Após a segunda metade do século XIX, o Estado brasileiro se transformou no maior agente condutor do sistema de transporte e comunicações no Brasil. Na navegação, atuava por meio de subvenção às companhias de navegação e também como proprietário direto de empresas, como a Companhia de Navegação Lloyd Brasileiro, a Companhia Nacional de Navegação Costeira e inúmeras outras empresas regionais de menor porte. No setor ferroviário, a intervenção estatal ocorria de forma indireta, por meio da garantia de juros ou da subvenção quilométrica concedida às companhias ferroviária, e direta sendo proprietário, que se dava 
quando uma empresa falia e seu patrimônio era encampado pelo Estado. No setor portuário, excluindo os portos de Santos e Manaus, os demais eram todos administrados e operados por companhias docas estatais. No serviço de postagem, os correios eram uma exclusividade do Estado e sempre operaram com déficit financeiro. Nos serviços de telégrafos, a situação não era diferente. A grande maioria das linhas nacionais era de propriedade do Estado, que também operava com déficit financeiro. Excluindo algumas linhas no Norte, as internacionais e as vinculadas às ferrovias, as demais dependiam da assistência técnica e administrativa de funcionários públicos. Portanto, transportes e comunicações, pedras angulares do sistema nacional de economia e da organização do território no Brasil, dependiam direta e indiretamente do Estado. Levar ferrovias, navegação, portos, correios e telégrafos aos pampas gaúchos, cerrado mato-grossense, sertão baiano e selva amazônica era uma forma de adensar o Estado brasileiro em seu território.

Com a disponibilidade das tecnologias difundidas mundialmente pela expansão dos serviços dos telégrafos e em função da necessidade de o Brasil estabelecer comunicação mais rápida em todo o seu território e com outras nações, o telégrafo elétrico foi introduzido nas comunicações brasileiras em 11 de maio de 1852, por iniciativa de Euzébio de Queiróz e Guilherme Capanema. Se tomarmos 1837 como o ano em que os telégrafos são introduzidos comercialmente nos Estados Unidos e 1838, na Inglaterra, o atraso de 15 anos na primeira metade do século XIX pode ser considerado relativamente pouco dadas as condições da economia e da sociedade brasileira, que careciam de uma base social mais orgânica e de uma estrutura produtiva mais avançada. O Brasil sempre foi um país de dimensões continentais, portanto qualquer extensão da linha de telégrafos implicaria vultosos investimentos e trabalho hercúleo.

A primeira linha a entrar em operação, em 11 de maio de 1852, foi entre a residência oficial do Imperador, na Quinta da Boa Vista, e o Quartel do Campo de Santana, com uma extensão de 4.300 metros. Em seguida, foram estabelecidas comunicações entre os ministérios, quartéis, arsenais e a cidade de Petrópolis. Em 15 de dezembro de 1858, o serviço foi aberto ao público, e, no ano seguinte, a extensão total na cidade do Rio de Janeiro já era de 64.982 metros. Por conta da Guerra do Paraguai (1864-1870), o Estado brasileiro tomou a decisão estratégica de levar os serviços de telégrafos até o Rio Grande do Sul. Em 1866, a linha chegou a Desterro e, no ano seguinte, a Porto Alegre. Após o término da guerra, continuaram os trabalhos de expansão da linha no território brasileiro integrando a capital com as principias cidades do Sul e Nordeste. Em 1870, a linha foi estendida até Pelotas; em 1871, chegou a Curitiba e à fronteira com o Uruguai. Em direção ao Nordeste, em 1873, foram inauguradas as estações de Itapemirim, Recife e Maceió. Nesse mesmo ano foram abertas as linhas de Santos e São Paulo. Em 1874, foi a vez das cidades de Salvador e Aracajú; em 1875, Paraíba; em 1876, Natal. Nas décadas 
seguintes, a linha foi estendida para o Norte e Centro-Oeste, com a inauguração da estação de São Luiz e Teresina, em 1884, e Belém em 1886. Goiás e Cuiabá passaram a ter acesso ao serviço de telégrafos em 1890 e 1891, respectivamente. A capital mineira, Belo Horizonte, que ainda estava em construção, recebeu o telégrafo em 1895. No Amazonas, a telegrafia chegou por meio de cabos fluviais colocados pela companhia inglesa Amazon Telegraph Company, no ano de 1896. Ao Centro-Oeste, os telégrafos chegaram em 1906, junto com a expedição do marechal Cândido Rondon. Nas linhas internacionais, o Brasil se integrou com a Europa em 1874, Uruguai em 1879, Argentina em 1883 e Estados Unidos e Senegal em 1892 (REPARTIÇÃO GERAL DOS TELÉGRAFOS, 1909).

No que tange ao ordenamento administrativo dos serviços telegráficos, em 17 de março de 1855 foi criada a Direção Geral dos Telégrafos Elétricos, que estava sob o controle do Ministério dos Negócios do Império. Por meio do Decreto $\mathrm{n}^{\circ}$ 3.288, de 20 de junho de 1864, foi aprovado o regulamento da Repartição Geral dos Telégrafos, que passou a ser subordinada ao Ministério da Agricultura, Comércio e Obras Públicas. Ao longo de todo o período imperial, durante 37 anos, a Repartição Geral dos Telégrafos foi dirigida pelo "inventor" dos telégrafos no Brasil, o Barão de Capanema.

Em um breve interregno entre 1890 e 1891, a Repartição foi transferida para o Ministério da Instrução Pública, Correios e Telégrafos. No ano de 1892, após a extinção do efêmero ministério, a Repartição passou para o comando do Ministério da Indústria, Viação e Obras Públicas. Em 1909, em uma nova reforma administrativa, o ministério foi desmembrado e passou a ser somente Ministério da Viação e Obra Públicas, ao qual ficou subordinada a Repartição Geral dos Telégrafos. Com relação aos disciplinamentos jurídicos da Repartição, após a aprovação do primeiro regulamento, em 1864, até 1930 foram sancionados mais cinco novos regulamentos: Decreto $\mathrm{n}^{\circ} 4.633$, de 28 de dezembro de 1870, Decreto $\mathrm{n}^{\circ} 1.663$, de 30 de janeiro de 1894, Decreto $n^{\circ} 4.053$, de 24 de junho de 1901, Decreto $n^{\circ}$ 9.148, de 27 de novembro de 1911 e Decreto $n^{\circ} 11.520$, de 10 de março de 1915.

Excluindo apenas a linha do Norte, que era de propriedade da Amazon Telegraph Company, as linhas da Western Telegraph Company, que cobriam o litoral brasileiro, e as linhas internacionais (Compagnie Française des Cables Télégraphiques e a Central $\mathcal{E}$ South American Telegraph), a rede de telegráfico brasileira era um serviço estatal (REPARTIÇÃO GERAL DOS TELÉGRAFOS, 1922). Nos países de capitalismo organizado, grande parte dos serviços de telégrafos era executada por companhias privadas. Como no Brasil as formas superiores de organização capitalista ainda estavam atrofiadas, com deficiência em sua estrutura financeira e produtiva, os serviços de telégrafos foram assumidos pelo Estado. 


\section{Telégrafos em Santa Catarina: definindo Território e ampliando as Co- municações}

Para melhor compreendermos a expansão da rede de telégrafos em Santa Catarina como parte do adensamento do estado no território, dividimos este tópico em três seções: de 1866 a 1900, de 1900 a 1918 e de 1918 a 1930. O critério de escolha dos períodos está relacionado aos momentos de expansão e estagnação dos investimentos na definição de novos ramais e inauguração de estações telegráficas. No Anexo A, há seis mapas nos quais é possível acompanhar a trajetória de expansão dos telégrafos em Santa Catarina entre 1867 e 1930.

\subsection{Instalação e Início da Interiorização: 1866-1900}

A chegada dos telégrafos em Santa Catarina ocorreu em função das demandas advindas do Ministério da Guerra que, em 1865, se envolveu na Guerra do Paraguai. Dada a necessidade estratégica de manter uma comunicação rápida entre a província do Rio Grande do Sul e a Corte, a Repartição Geral dos Telégrafos recebeu a incumbência de levar a rede de telégrafos até as províncias do Sul. A empreitada deveria ser executada no menor intervalo de tempo possível. No dia 9 de janeiro de 1866, foi inaugurada a estação em Desterro. No ano seguinte, no dia $1^{\circ}$ de janeiro, em Itajaí; em 4 de janeiro, na cidade de Laguna; e, no dia 16 de fevereiro, chegou a São Francisco. Essas foram as quatro primeiras estações telegráficas instaladas em Santa Catarina. A principal linha tronco ia do Rio de Janeiro a Porto Alegre, tinha aproximadamente 1.800 quilômetros e era formada por 22 estações. No território catarinense, a linha tronco tinha 558.131 metros e seguia, quando possível, o percurso da estrada do litoral. Ademais, o litoral catarinense era mais povoado do que o planalto serrano e oferecia mais segurança para a manutenção da linha (REPARTIÇÃO GERAL DOS TELÉGRAFOS, 1860-1872).

Nas duas décadas seguintes, Santa Catarina recebeu um número expressivo de novos imigrantes europeus que foram alocados nas colônias existentes ou fundaram novos núcleos populacionais. No vale do Itajaí, Blumenau transformou-se no principal polo de irradiação da colonização catarinense em direção ao planalto. No litoral norte, essa função coube a Joinville, que levou o movimento imigratório para o planalto norte e para o Vale do Itapocu. No sul da província, Urussanga e Criciúma constituíram-se nas duas principais colônias da região, de onde partiam os imigrantes que fundaram novos núcleos. Merece destaque o movimento de ocupação das margens da estrada de Lages, que ligava o litoral ao planalto, onde foram fundados pequenos núcleos coloniais. No planalto serrano, onde não houve colônias de imigrantes, a cidade de Lages e os povoados de Curitibanos e Campos Novos garantiam 
a presença do Estado provincial no território do sertão da terra firme em direção ao oeste. Seria sobre esse mosaico demográfico do território catarinense que a rede de telégrafos se estenderia no século XIX (GOULARTI FILHO, 2007).

Na década de 1870, foi inaugurada apenas mais uma estação, a de Joinville, que entrou em operação no dia 15 de março de 1879, a partir de um ramal proveniente de Morretes (PR), portanto fora da linha tronco que passava por Santa Catarina. Na década de 1880, foram mais três novas estações, a de Tubarão (27 de abril de 1882), Fortaleza de Santa Cruz Anhatomirim (12 de fevereiro de 1888) e Araçatuba (sul da ilha de Santa Catarina, em 13 de novembro de 1889). O ramal de Tubarão provinha da linha tronco de Laguna e media 26.400 metros. Podemos afirmar que apenas Tubarão servia como estação para o atendimento do público, pois tanto Anhatomirim como Araçatuba ficavam em uma fortaleza que pertencia ao Ministério da Marinha. Portanto, entre os anos de 1868 e 1889, sob a direção do Barão de Capanema na Repartição Geral dos Telégrafos, foram abertas em Santa Catarina somente duas novas estações destinadas ao atendimento ao público (REPARTIÇÃO GERAL DOS TELÉGRAFOS, 1873-1888).

Na década de 1890, houve uma extensão mais significativa dos telégrafos em Santa Catarina com a construção de ramais até Blumenau (10 de junho de 1890), Brusque ( $1^{\circ}$ de janeiro de 1894) e São Bento (31 de dezembro de 1896), alcançando as principias colônias de imigrantes. Em 31 de dezembro de 1896, foi inaugurada a estação em Lages, que atendia os objetivos do governo catarinense de finalmente integrar as comunicações entre a capital e o planalto serrano. Lages foi integrada à rede por meio do ramal que partia de Itajaí, passava por Blumenau e subia a Serra Geral, em uma extensão de 205.581 metros. Com essa nova obra, a linha telegráfica em Santa Catarina passou para 979.116 metros (REPARTIÇÃO GERAL DOS TELÉGRAFOS, 1889-1900). Apesar de o telégrafo chegar a Lages apenas em 1896, o governo provincial catarinense vinha se empenhando para executar essa obra desde 1888, quando aprovou a Lei $\mathrm{n}^{\circ} 1.205$, de 21 de setembro de 1888, que autorizava o presidente da província a utilizar a verba de 20:000 $\$ 000$ para auxiliar na construção da linha telegráfica até a cidade de Lages. O ponto de partida seria designado pela Repartição Geral dos Telégrafos (SANTA CATARINA, 1888).

Os anos de 1890 foi o período em que mais foram abertas linhas postais, espraiando-se pelas várias colônias do sul, Vale do Itajaí e planalto norte. O mesmo movimento de melhorais materiais também ocorreu em diversas estradas que seguiam do litoral em direção ao interior, como as obras de construção e reparos na estrada de Lages, estrada Dona Francisca, estrada de Blumenau a Curitibanos, estrada do litoral e estrada de Tubarão. Merece destaque a inauguração da EFDTC, em $1^{\circ}$ de setembro de 1884, entre Imbituba, Laguna, Tubarão e Lauro Müller, com a presença de telégrafos nas estações ferroviárias. Essa combinação de expansão demográfica e melhorais nos transportes e nas comunicações estava diretamente 
relacionada ao aumento do fluxo mercantil com a formação do complexo carbonífero catarinense no sul e do complexo ervateiro no planalto norte; com a consolidação das atividades produtivas ligadas ao setor alimentício e têxtil-vestuário nas colônias do Vale do Itajaí e em Joinville; e com a expansão contínua da pecuária e do tropeirismo do planalto serrano em direção ao litoral sul e Vale do Itajaí. A combinação dessas várias camadas geoeconômicas formou um sistema regional de economia e contribuiu para o adensamento do estado no território.

Quadro 1 - Estações de telégrafos inauguradas em Santa Catarina (1866-1930)

\begin{tabular}{|c|c|c|c|}
\hline Localidade & $\begin{array}{c}\text { Data da } \\
\text { inauguração }\end{array}$ & Localidade & $\begin{array}{c}\text { Data da } \\
\text { inauguração }\end{array}$ \\
\hline Florianópolis & $9 / 1 / 1866$ & Criciúma & $28 / 4 / 1922$ \\
\hline Itajaí & $1 / 1 / 1867$ & Nova Veneza & $28 / 4 / 1922$ \\
\hline Laguna & $4 / 1 / 1867$ & Itoupava Seca & $7 / 9 / 1923$ \\
\hline São Francisco & $16 / 2 / 1867$ & Imbituba & $1 / 2 / 1924$ \\
\hline Joinville & $15 / 4 / 1879$ & Luiz Alves & $27 / 11 / 1927$ \\
\hline Tubarão & $27 / 4 / 1882$ & Santo Amaro & $27 / 11 / 1927$ \\
\hline $\begin{array}{l}\text { Fortaleza de Santa Cruz de } \\
\text { Anhatomirim }\end{array}$ & $12 / 2 / 1888$ & Pato Branco & $1 / 1 / 1928$ \\
\hline Araçatuba (Barra do Sul) & $13 / 11 / 1889$ & Porto União & $3 / 5 / 1928$ \\
\hline Tijucas & $17 / 2 / 1890$ & Bom Retiro & $23 / 5 / 1928$ \\
\hline Blumenau & $10 / 6 / 1890$ & Rancho Queimado & $23 / 5 / 1928$ \\
\hline Araranguá & $22 / 4 / 1893$ & Teresópolis & $23 / 5 / 1928$ \\
\hline Brusque & $1 / 1 / 1894$ & Jaraguá & $28 / 5 / 1928$ \\
\hline Garopaba & $22 / 2 / 1896$ & Mondai & $28 / 12 / 1928$ \\
\hline Lages & $31 / 12 / 1896$ & Mafra & $10 / 1 / 1929$ \\
\hline São Bento & $31 / 12 / 1896$ & Sombrio & $15 / 3 / 1929$ \\
\hline Indaial & $6 / 2 / 1900$ & Passo do Sertão & $17 / 4 / 1929$ \\
\hline Pouso Redondo & $17 / 7 / 1901$ & Braço do Norte & $8 / 6 / 1929$ \\
\hline Palhoça & $5 / 1 / 1903$ & São Martinho & $8 / 6 / 1929$ \\
\hline Campos Novos & $9 / 5 / 1903$ & Orleans & $24 / 7 / 1929$ \\
\hline São Joaquim & $11 / 2 / 1904$ & Dionísio Cerqueira & $27 / 7 / 1929$ \\
\hline Jaguaruna & $14 / 1 / 1905$ & Rio Negrinho & $18 / 11 / 1929$ \\
\hline Porto Belo & $16 / 6 / 1906$ & Lauro Müller & $9 / 1 / 1930$ \\
\hline Urussanga & $8 / 11 / 1906$ & Índios & $15 / 1 / 1930$ \\
\hline São José & $12 / 12 / 1906$ & Praia Grande & $25 / 2 / 1930$ \\
\hline Mirim & $7 / 2 / 1907$ & Passo dos Índios & $20 / 3 / 1930$ \\
\hline Canoinhas & $10 / 4 / 1919$ & Taió & $31 / 5 / 1930$ \\
\hline Itapera & $22 / 12 / 1919$ & Boiteuxburgo & $21 / 7 / 1930$ \\
\hline Pedras Grandes & $10 / 9 / 1920$ & Itaiópolis & $21 / 8 / 1930$ \\
\hline Estreito & $19 / 9 / 1920$ & & \\
\hline
\end{tabular}

Fonte: REPARTIÇÃO GERAL DOS TELÉGRAFOS (1860-1888), REPARTIÇÃO GERAL DOS TELÉGRAFOS (1897-1931). 


\subsection{Expansão e Integração da Rede: 1900-1918}

No período que abrange os anos de 1900 a 1918, o Brasil já estava integrado por meio de cabos submarinos com a Europa, a América do Norte e a África. Por via terrestre, a linha que se estendia para o sul se conectava com Uruguai e Argentina, seguindo para o Chile e os países andinos. Os trabalhos de levar a rede de telégrafos ao Centro-Oeste e ao Norte, além de seguir em direção à Bolívia, ficou a cargo do marechal Cândido Rondon, que fez de sua expedição uma epopeia nacional.

A divisão administrativa dos serviços telegráficos manteve-se a mesma desde sua expansão acelerada. Excluindo apenas a linha do Norte e os cabos atlânticos, o restante da rede era de propriedade do Estado, que mantinha toda a estrutura em funcionamento operando com déficits financeiros constantes. A exemplo de outros serviços estratégicos para o país, os telégrafos também eram imprescindíveis, portanto, os déficits poderiam ser questionados, mas os serviços jamais poderiam ser abandonados.

Desde a inauguração da primeira estação em Desterro, no dia 9 de janeiro de 1866, até o final do século XIX, foram abertas 16 estações em Santa Catarina, distribuídas em sua maioria pelo litoral e algumas no interior, com destaque para Blumenau e Lages. Entre os anos de 1902 e 1907, houve um aumento significativo de estações inauguradas, quando passou de 17 para 25 estações. A expansão mais significativa foi a entrada em operação da linha Lages-Curitibanos-Campos Novos, inaugurada em 1903, com 138.807 metros. Com essa nova linha, Campos Novos se conectou a Itajaí pela mesma rede que passava em Blumenau, somando ao todo um extenso ramal de 344.388 metros. No ano seguinte, as obras de extensão da linha seguiram em direção ao oeste até chegar à cidade de Palmas, no Paraná. Em 1905, com a inauguração da linha Campos Novos-Palmas, com 159.500 metros, foi fechado o grande circuito do sul brasileiro de Curitiba a Porto Alegre (REPARTIÇÃO GERAL DOS TELÉGRAFOS, 1901-1907).

Durante todo o século XIX e até o desfecho final da Guerra do Contestado (1912-1916) e da Questão dos Limites (1895-1916), todo o território do oeste e do planalto norte catarinenses estava em litígio com o Paraná. O governo paranaense reivindicava as terras contestadas alegando que lhe pertenciam desde 0 seu desmembramento de São Paulo, em 1853. Por sua vez, o governo catarinense argumentava que as terras disputadas tinham sido incorporadas por meios legais. Quando foi assinado o Acordo de Limites, em 20 de outubro de 1916, o ganho de causa foi dado a Santa Catarina. O estado catarinense sempre definiu como prioridade expandir e demarcar seu território em direção ao planalto e o oeste. Lages, fundada em 1766, era a fortaleza que garantia a presença do estado no planalto serrano; e Campos Novos, criado em 1854, era o posto avançado em direção ao oeste. Ambas estavam sob a jurisdição do governo catarinense, que se responsa- 
bilizava por colocá-las em contato com Desterro por meio da abertura de estradas (estrada de Lages e estrada de Campos Novos), de linhas postais (aberta em 1882) e de rede de telégrafo.

Outra importante linha aberta em 1904 foi entre Lages e São Joaquim, com 71.193 metros. Com a inauguração da estação em São Joaquim, em 11 de fevereiro de 1904, e da estação de Urussanga, no sul do estado, em 8 de novembro de 1906, começava a ser estudada a possibilidade de interligar a rede do litoral sul com a do planalto serrano, fechando mais um circuito regional. Lages foi interligada à rede gaúcha com a expansão dos fios até a cidade de Vacarias, em 1905, com 97.690 metros. Além da integração de Campos Novos com Erechim (RS), em 1908, com 50.145 metros.

No sul do estado, onde já operavam as estações privadas da EFDTC entre Imbituba, Laguna, Tubarão e Lauro Müller, em 1904 foi estendida a linha pública de Tubarão até Jaguaruna, com 8.753 metros, e, em seguida, em 1906, para a colônia de Urussanga, com 44.955 metros. No litoral, entre 1903 e 1904, ocorreu a ligação Itajaí-Camboriú e Porto Belo-Tijucas-Nova Trento. No vale do Itapocu, Jaraguá do Sul se conectou a Corupá em uma linha com 61.300 metros, cruzando a íngreme Serra do Mar em 1911. Seguindo em direção ao litoral, Jaraguá integrou-se com Penha em 1913 (REPARTIÇÃO GERAL DOS TELÉGRAFOS, 1904-1911).

Portanto, no curto intervalo de 1903 a 1906, a rede telegráfica em Santa Catarina fechou seu circuito com o Paraná e o Rio Grande do Sul. E para demarcar a presença do estado no território em litígio no oeste, Campos Novos integrou-se à rede catarinense. Lages consolidou-se com um entroncamento no planalto servindo de base para ramais em direção ao litoral sul, planalto norte e oeste. O mesmo papel que Lages ocupava em relação à rede de telégrafos também ocorria com o sistema viário, cujas principais estradas seguiam em direção ao interior, no intuito de chegar até a cidade serrana.

Quadro 2 - Ramais telegráficos abertos em Santa Catarina (1882-1930)

\begin{tabular}{|l|l|l|l|l|l|}
\hline Ramal & $\begin{array}{l}\text { Extensão } \\
(\mathbf{m})\end{array}$ & Ano & Ramal & $\begin{array}{l}\text { Extensão } \\
(\mathbf{m})\end{array}$ & Ano \\
\hline Laguna-Tubarão & 26.400 & 1882 & Passo dos Índios-Mondaí & 68.000 & 1928 \\
\hline $\begin{array}{l}\text { Florianópolis-Fortaleza de } \\
\text { Santa Cruz de Anhatomirim }\end{array}$ & 7.350 & 1888 & Luiz Alves-Massaranduba & 17.400 & 1928 \\
\hline Florianópolis-Araçatuba & 33.700 & 1889 & Teresópolis-Anitápolis & 13.682 & 1928 \\
\hline Itajaí-Tijucas & 42.517 & 1890 & Lages-Bom Retiro & 938.500 & 1928 \\
\hline Tubarão-Araranguá & 7.833 & 1893 & Campo Erê-Barracão & 49.312 & 1928 \\
\hline Itajaí-Brusque & 35.104 & 1894 & Araranguá-Passo do Sertão & 32.500 & 1928 \\
\hline Itajaí-Lages & 205.581 & 1895 & São Bento-Rio Negro & 14.600 & 1928 \\
\hline Joinville-São Bento & 62.500 & 1896 & Santo Amaro-Bom Retiro & 98.000 & 1928 \\
\hline $\begin{array}{l}\text { Lages-Curitibanos-Campos } \\
\text { Novos }\end{array}$ & 138.807 & 1903 & São Bento-Mafra-Três Barras & 116.688 & 1929 \\
\hline
\end{tabular}

Continua... 
Conclusão.

\begin{tabular}{|c|c|c|c|c|c|}
\hline Ramal & $\begin{array}{l}\text { Extensão } \\
(\mathrm{m})\end{array}$ & Ano & Ramal & $\begin{array}{l}\text { Extensão } \\
\text { (m) }\end{array}$ & Ano \\
\hline Itajaí-Camboriú & 4.537 & 1903 & Rio do Sul-Trombudo Central & 18.000 & 1929 \\
\hline Lages-São Joaquim & 71.193 & 1904 & Rio Bontio-Angelina & 15.530 & 1929 \\
\hline Tubarão-Jaguaruna & 8.753 & 1904 & Tubarão-Braço do Norte & 26.600 & 1929 \\
\hline Tijucas-Nova Trento & 31.774 & 1904 & Mafra-Itaiópolis-Paraguassu & 32.210 & 1929 \\
\hline Tijucas-Porto Belo & 4.497 & 1904 & Mondaí-Itapiranga & 55.000 & 1929 \\
\hline Joinville-São Francisco-Parati & 11.600 & 1904 & Braço do Norte-Grão Pará & 10.000 & 1929 \\
\hline $\begin{array}{l}\text { Campos Novos-Palmas (fecha } \\
\text { circuito Porto Alegre-Curitiba) }\end{array}$ & & 1905 & $\begin{array}{l}\text { Boa Vista-Pinheiral- } \\
\text { Boiteauxburgo }\end{array}$ & 51.000 & 1929 \\
\hline Lages-Vacarias & 97.690 & 1905 & São Miguel-Ganchos & 23.000 & 1929 \\
\hline Itajaí-Farol da Cabeçuda & 3.500 & 1906 & Rio do Sul-Taió & 31.000 & 1929 \\
\hline Tubarão-Urussanga & 44.955 & 1906 & Herval do Oeste-Xanxerê & 140.000 & 1929 \\
\hline Mirim-Imaruí & 25.923 & 1906 & Tubarão-Treze de Maio & 24.000 & 1929 \\
\hline Campos Novos-Palmas & 159.500 & 1906 & Nova Trento-Brusque & 28.000 & 1929 \\
\hline Campos Novos-Erechim/RS & 50.145 & 1908 & $\begin{array}{l}\text { Passo do Sertão-Praia } \\
\text { Grande }\end{array}$ & 18.000 & 1929 \\
\hline Jaraguá-Corupá & 61.300 & 1911 & Lages-Vacarias (duplicação) & & 1929 \\
\hline Penha-Rio Itapocu & & 1913 & $\begin{array}{l}\text { Lages-Curitibanos } \\
\text { (duplicação) }\end{array}$ & & 1929 \\
\hline Santa Cecilia-Canoinhas & 108.820 & 1918 & $\begin{array}{l}\text { São José-São Pedro de } \\
\text { Alcântara }\end{array}$ & 23.939 & 1929 \\
\hline $\begin{array}{l}\text { Urussanga-Nova Veneza- } \\
\text { Cocal }\end{array}$ & 38.330 & 1921 & $\begin{array}{l}\text { Hamônia-Nova Bremen- } \\
\text { Nova Breslau }\end{array}$ & 30.000 & 1929 \\
\hline Ascurra-Rodeio & & 1924 & $\begin{array}{l}\text { Poço Preto-Vila Nova-Santa } \\
\text { Cruz }\end{array}$ & 14.000 & 1929 \\
\hline Blumenau-Itapoava Seca & & 1925 & Gravatá-Capivari & 15.000 & 1929 \\
\hline Passo Bormann-Mondai & 36.000 & 1927 & Alfândega-Sambaqui & 23.000 & 1929 \\
\hline Pato Branco-Campo Erê & 60.000 & 1927 & $\begin{array}{l}\text { Urussanga-Nova Treviso- } \\
\text { Nova Beluno } \\
\end{array}$ & 36.000 & 1929 \\
\hline Canoinhas-Porto União & 98.000 & 1927 & Tubarão-São Joaquim & 130.000 & 1929 \\
\hline Joinville-Jaraguá & 47.500 & 1927 & $\begin{array}{l}\text { Porto União-Bom Retiro (até } \\
\text { Galícia) }\end{array}$ & 33.528 & 1930 \\
\hline São João Batista-Boa Vista & 15.680 & 1927 & Cruzeiro-Itá & 24.066 & 1930 \\
\hline Penha-Luiz Alves & 37.000 & 1927 & Barracão-Rio do Sul & 48.460 & 1930 \\
\hline Campos Novos-Rio Capinzal & 54.225 & 1927 & $\begin{array}{l}\text { Capitania dos Portos-Base de } \\
\text { Aviação Naval } \\
\end{array}$ & 13.450 & 1930 \\
\hline Palhoça-Bom Retiro & 111.000 & 1927 & Colônia Vieira-Papanduva & 22.602 & 1930 \\
\hline Indaial-Encruzilhada & 24.080 & 1927 & & & \\
\hline
\end{tabular}

Fonte: REPARTIÇÃO GERAL DOS TELÉGRAFOS (1860-1888), REPARTIÇÃO GERAL DOS TELÉGRAFOS (1897-1931).

Na década de 1910, começou o processo de colonização do oeste e extremo oeste catarinense por meio do movimento migratório de ítalo e teuto-brasileiros que saíam de colônias gaúchas em direção às terras catarinenses. Outro evento 
significativo no oeste foi a entrada em operação, em 1910, do trecho catarinense da EFSPRG que margeava boa parte do Rio do Peixe. Com a proliferação de novas vilas e cidades, era natural que fosse solicitada junto à Repartição Geral dos Telégrafos a construção de ramais em direção ao extremo oeste. Porém, dois acontecimentos significativos retardaram a chegada dos telégrafos à região: um de ordem externa, a Primeira Guerra Mundial (1914-1918), que dificultava a importação de equipamento e cabos; e outro de ordem interna, a Guerra do Contestado (1912-1916), que tornava a região muito instável para a realização dos serviços de colocação dos postes e fios. Com o fim da Guerra e a assinatura do Acordo de Limites, o governo catarinense tratou de demarcar definitivamente sua presença no território contestado, com a criação dos municípios de Joaçaba e Chapecó, base para futuros desmembramentos.

Com o fechamento do grande circuito telegráfico sul brasileiro, a rede catarinense foi subdivida em nove seções assim distribuídas:

a) primeira seção: São Bento a São Francisco (113.886 m): estações de São Bento, Campo Alegre, Joinville, São Francisco e Parati;

b) segunda seção: Joinville a Itajaí na linha tronco e ramal para Blumenau (154.559 m): estações de Joinville, Blumenau, Farol da Cabeçuda, Penha, Brusque e Itajaí;

c) terceira seção: Blumenau a Lages (215.786 m): estações de Blumenau, Aquidaban, Indaial, Hamônia, Rio do Sul, Pouso Redondo e Lages;

d) quarta seção: Lages a Vacaria e Lages a São Joaquim (168.545 m): estações de Lages, São Joaquim e Painel;

e) quinta seção: Curitibanos a Palmas (217.742 m): estações de Curitibanos, Campos Novos e Herval do Oeste;

f) sexta seção: Itajaí (bifurcação) a Florianópolis (tronco) (177.804 m): estações de Itajaí, Camboriú, Porto Belo, Nova Trento, Fortaleza de Santa Cruz de Anhatomirim, Florianópolis, Araçatuba, Tijucas e Baguaçu;

g) sétima seção: Florianópolis (bifurcação no Estreito) a Tubarão (169.749 m): estações de Florianópolis, Estreito, São José, Palhoça, Garopaba, Laguna, Imaruí e Mirim;

h) oitava seção: Tubarão a Torres (195.138 m): estações de Tubarão, Azambuja, Urussanga, Jaguaruna, Araranguá e Barra do Araranguá;

i) nona seção: Lages a Curitibanos (67.638 m): estações de Lages e Curitibanos (SANTA CATARINA, 1914).

Além das estações administradas pela Repartição Geral dos Telégrafos, de caráter público, também havia as estações das companhias ferroviárias que operavam com tráfego mútuo (público) ou estranho (privado). A EFDTC possuía 17 estações mútuas, cujos serviços eram de acesso ao público. Já a EFSC, que cortava o vale do Itajaí, tinha em sua linha 13 estações que eram de uso exclusivo da companhia ferroviária. 
Santa Catariana chegou ao final de década de 1910 com um sistema regional de economia mais coeso e estendido. Ferrovias, navegação, estradas, linhas postais e telégrafos permitiam uma múltipla comunicação entre os diversos agentes econômicos e sociais. Com o advento da telefonia, a Repartição Geral dos Telégrafos começou a ofertar esses serviços inaugurando estações telefônicas exclusivas ou operando conjuntamente os dois serviços - telegrafia e telefonia - em uma mesma estação. A primeira estação telefônica inaugurada em Santa Catarina foi a de São Bento, em 31 de dezembro de 1896. Em 1904, já eram quatro estações; em 1910, oito; e, em 1916, estavam em funcionamento 12 estações telefônicas. A partir desse momento, nos planos de expansão dos serviços de comunicações, necessariamente deveria ser incluída a telefonia pública. Mesmo que os serviços telefônicos tenham iniciado como uma concessão privada e municipal, o estado não poderia ficar ausente em regiões onde os serviços telefônicos ofereciam baixa rentabilidade (REPARTIÇÃO GERAL DOS TELÉGRAFOS, 1910-1916).

Gráfico 1 - Evolução do número de estações de telégrafos em Santa Catarina (1866-1930)

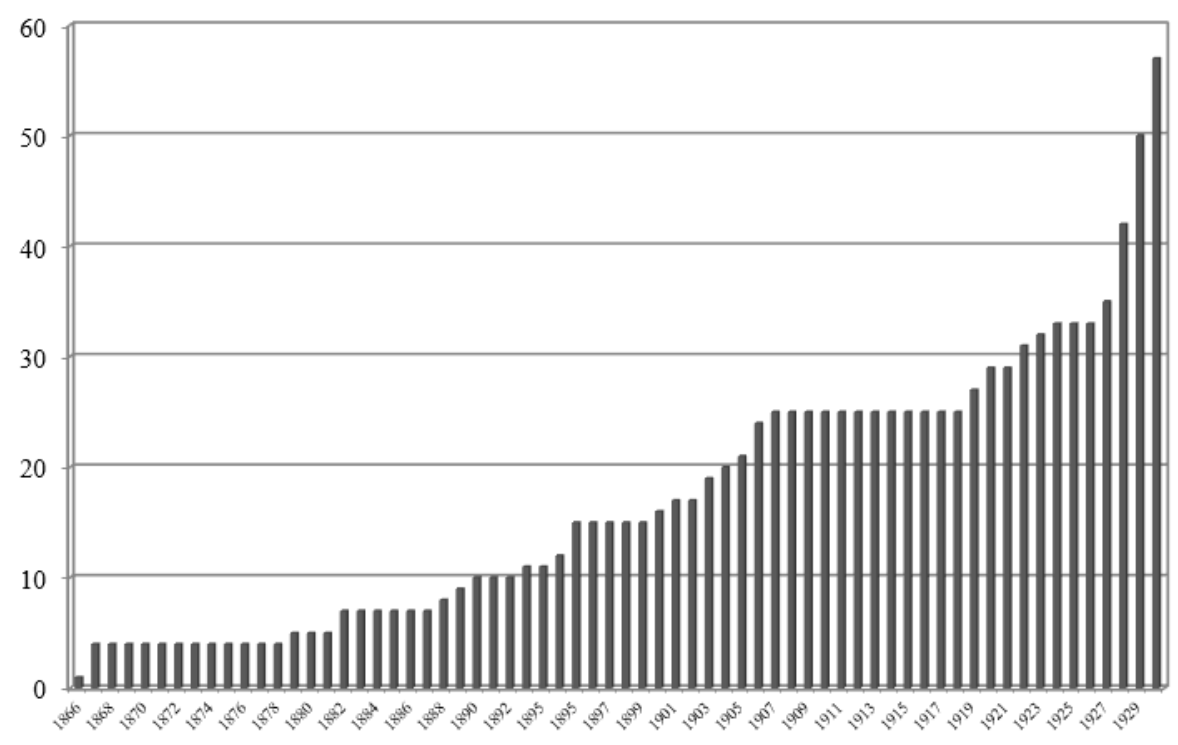

Fonte: REPARTIÇÃO GERAL DOS TELÉGRAFOS (1860-1888), REPARTIÇÃO GERAL DOS TELÉGRAFOS (1897-1931). 


\subsection{Formação do Sistema e Novos Serviços de Comunicações: 1918-1930}

O ritmo de expansão da rede de telégrafos no Brasil estava associado ao grau de desenvolvimento de suas forças produtivas e da capacidade de financiar novos investimentos. Como a maior parte da rede terrestre era propriedade do Estado e o déficit sempre foi um fantasma que rondou a Repartição Geral dos Telégrafos - qualquer expansão da rede implicaria mais gastos orçamentários. Os anos de 1920 representaram para a economia brasileira um momento de diversificação de sua estrutura produtiva e comercial. A expansão e o desdobramento da acumulação gerada pelos complexos regionais exportadores possibilitaram o surgimento de novas fábricas, atividades comerciais e serviços nas principais cidades brasileiras (CANO, 1990). No setor de transportes, o Brasil já dispunha de um amplo sistema ferroviário e de uma frota mercante nacional que atendia toda a costa atlântica e as maiores bacias fluviais, além de que se começava a desenhar uma rede viária destinada aos veículos automotores (NETTO, 1974).

Se olharmos para a economia catarinense ao longo do final do século XIX e início do XX, vamos perceber que o padrão de crescimento de sua economia era dado pela pequena produção mercantil, a qual tinha baixa capacidade de acumulação e limitado poder de impulsionar mudanças estruturais. O resultado dessa combinação rebatia no sistema de transportes (GOULARTI FILHO, 2007). Assim também ocorria na telegrafia e nos serviços postais, que apresentavam ampliação lenta e contínua.

Na década de 1920, a economia catarinense ainda era comandada pelo mesmo padrão de crescimento, mas começava a assistir aos efeitos dos desdobramentos da expansão do complexo ervateiro no planalto norte, do complexo carbonífero no sul, da integração nacional da indústria têxtil e de vestuário de Blumenau e Brusque, da colonização acelerada do oeste e do surgimento da pequena indústria metalomecânica em Joinville. Dentro desse cenário de maior robustez da economia catarinense é que temos de entender o processo de ampliação do sistema de comunicações, com a inauguração de novos ramais e estações de telégrafos e com o início da popularização da telefonia.

Em 1918, havia em Santa Catarina 25 estações telegráficas, saltando para 57 em 1930, o maior crescimento do período analisado. Entre as estações inauguradas, podemos destacar a de Canoinhas (10 de abril de 1919), Criciúma (28 de abril de 1922), Porto União (3 de maio de 1928), Mafra (10 de janeiro de 1929), Sombrio (15 de março de 1929), Orleans (24 de julho de 1929), Dionísio Cerqueira (27 de julho de 1929) e Taió (31 de maio de 1929) (REPARTIÇÃO GERAL DOS TELÉGRAFOS, 1918-1929).

Tivemos dois momentos em que houve um crescimento mais expressivo no número de estações inauguradas: entre 1902 e 1906 (sete estações) e entre 1927 
e 1930 (27 estações). Ambos os períodos coincidem com a presença de um catarinense no comando do Ministério da Viação e Obras Públicas: Lauro Müller, de 15 de novembro de 1902 a 15 de novembro de 1906, e Victor Konder, de 15 de novembro de 1926 a 24 de outubro de 1930. Lauro Müller havia sido eleito governador em 1902 pela quinta vez, mas logo renunciou para Vidal Ramos, seu vice, assumir e, em seguida, partiu para a capital federal para tomar posse no ministério. E quando Victor Konder foi ministro, seu irmão Adolfo Konder foi governador de Santa Catarina.

Concomitantemente à inauguração das estações foram abertos novos ramais distribuídos pelo território catarinense. Ao todo, entre 1921 e 1930, foram 48 ramais, acrescendo à rede mais 1.889.280 metros. Em 1930, a extensão total da rede (tronco mais ramais) chegou a 3.810.547 metros. Entre os ramais inaugurados, destacam-se Herval do Oeste-Xanxerê, com 140.000 metros, integrando o vale do Rio do Peixe com o oeste; São Bento-Mafra-Três Barras, com 116.688 metros, conectando todos os municípios do planalto norte, uma vez que já estava em operação o ramal de Canoinhas-Porto União, com 98.000 metros; de Canoinhas seguia outra linha para Santa Cecília, 108.820 metros; do litoral, próximo a Florianópolis, entrou em operação o ramal Palhoça-Bom Retiro, com 110.000 metros; e, para finalmente integrar o litoral sul com o planalto serrano, foi aberta a linha entre Tubarão e São Joaquim, com 130.000 metros (REPARTIÇÃO GERAL DOS TELÉGRAFOS, 1920-1931). Em 1930, além da linha troco de Joinville a Torres, o sistema telegráfico em Santa Catarina era formado pelos seguintes circuitos:

a) Joinvile a Canoinhas: integrava o litoral norte com o planalto norte. Área do complexo ervateiro e madeireiro. Operava, na região, o ramal ferroviário da EFSPRG (de São Francisco a Porto União), a estrada Dona Francisca (de Joinville a Mafra) e diversas companhias de navegação fluvial nos rios Negro e Iguaçu (entre Mafra, Canoinhas e Porto União);

b) Itajaí a Lages: integrava o litoral, Vale do Itajaí e planalto serrano. Havia na região diversas atividades manufatureiras e comerciais, com destaque para a indústria têxtil e de vestuário. A região era servida pela EFSC (de Blumenau a Rio do Sul), pela estrada de Blumenau a Curitibanos e pela Companhia de Navegação Fluvial a Vapor Itajahy-Blumenau, no rio Itajaí-Açu;

c) Tubarão a Lages: integrava o litoral sul ao planalto serrano. No sul, havia o complexo carbonífero que era atendido pela a EFDTC (de Imbituba a Lauro Müller) e, em direção ao planalto, seguia a estrada de Tubarão;

d) Vacaria (RS) a Palmas (PR) e bifurcação para Clevelândia (PR): apesar de partir de municípios que não eram catarinenses, esse ramal cortava o oeste e se integrava ao planalto serrano, área da reserva de araucária e das frentes pioneiras. Acompanhando o Rio do Peixe, seguia o trecho catarinense da EFSPRG (de Porto União a Piratuba), além da estrada de Campos Novos; 
e) Curitibanos a Canoinhas: conectava o planalto serrano ao planalto norte em direção ao vale do rio Negro. Era a região do complexo ervateiro e madeireiro atendida pela estrada da mata (de Curitibanos a Mafra) e pela estrada de Canoinhas, além de pequenos trechos fluviais navegáveis;

f) Tijucas a Brusque: colocava em contato o litoral do Vale do Rio Tijucas com o Vale do Itajaí, grande área de colonização europeia e da pequena produção mercantil. Entre as duas cidades, havia estradas coloniais que se ramificavam em outros caminhos vicinais. Era o menor de todos os circuitos catarinenses;

g) Palhoça a Lages: integrava a região da capital com o planalto serrano. Área de intenso fluxo do comércio tropeiro que descia a Serra Geral em direção à capital catarinense. As duas cidades mantinham contatos pela estrada de Lages;

h) Clevelândia (PR) a Nonoai (RS): esse circuito ligava uma cidade paranaense a uma gaúcha, cruzando o oeste catarinense e tendo no meio as cidades de Chapecó e Xanxerê. Área de reserva da mata araucária e de colonização das frentes pioneiras do movimento migratório advindo do Rio Grande do Sul.

Com a expansão acelerada das linhas, o número de seções passou para 12 e foram incluídos o planalto norte, o oeste e a linha entre o litoral sul e o planalto serrano. Toda essa expansão, que possibilitou formar um sistema estadual de comunicações telegráficas, repercutiu diretamente no volume de telegramas que circularam dentro do território catarinense. Mesmo dispondo de uma série muito fragmentada, houve um crescimento exponencial nas três primeiras décadas do século XX. Em 1900, foram emitidos 47.964 telegramas, passando para 87.973, em 1910, e 148.775 em 1930 (REPARTIÇÃO GERAL DOS TELÉGRAFOS, 19001931). Esse aumento considerável de emissão de telegramas está associado ao alargamento da divisão social do trabalho e à formação do sistema regional de economia. 
Gráfico 2 - Evolução da extensão das linhas de telégrafos em Santa Catarina (18661930)

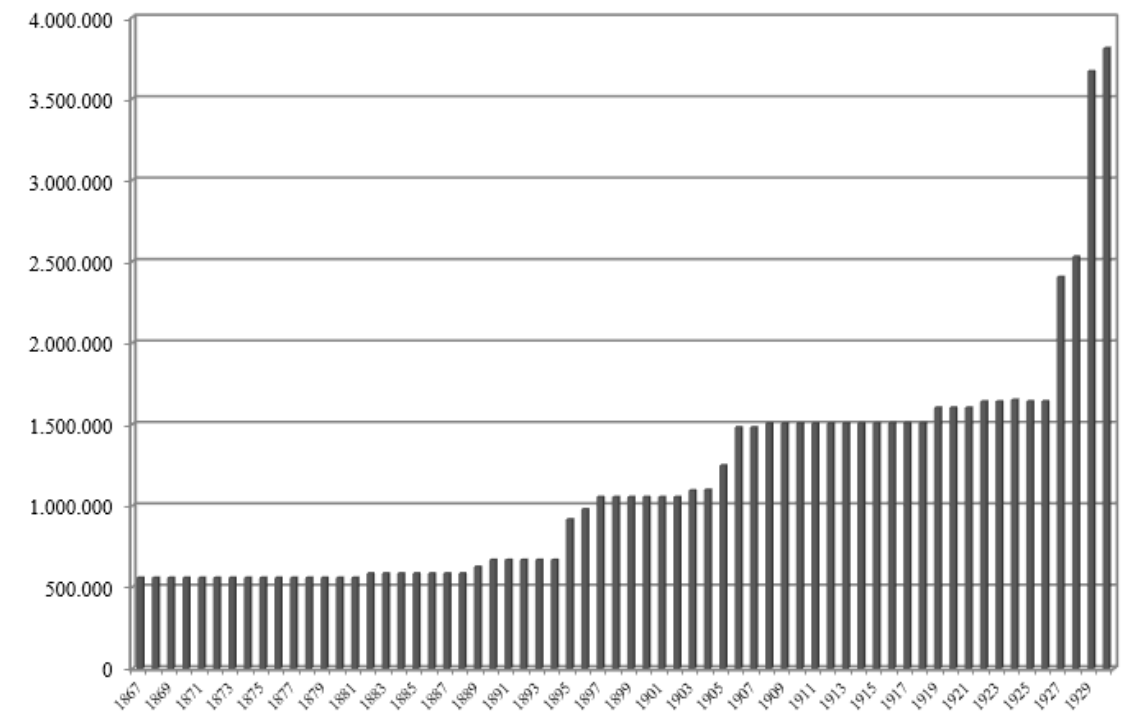

Fonte: REPARTIÇÃO GERAL DOS TELÉGRAFOS (1860-1888), REPARTIÇÃO GERAL DOS TELÉGRAFOS (1897-1931).

\section{Considerações Finais}

Transportes e comunicações estão subordinados à lógica da produção na mesma proporção em que o aumento da produção está condicionado à disponibilidade de uma rede de comunicações e de serviços de transportes. Reduzir espaço e tempo é uma exigência do capital para garantir sua valorização contínua. A constituição de uma ampla rede de telégrafos atende demandas sociais diversas que vão desde a garantia da valorização do capital, passando por estratégias militares, até o atendimento de demandas vinculadas ao mundo do trabalho, das artes e da cultura. Pelos telégrafos, eram transmitidas notícias de interesse pessoal e de grupos sociais das mais distintas ideologias.

Nos anos de 1920, ao mesmo tempo que houve uma rápida expansão da rede telegráfica em Santa Catarina, já estavam em operação os serviços telefônicos privados nas principais cidades catarinenses. Nas cidades onde não havia serviços telefônicos, a Repartição Geral dos Telégrafos se encarregou de abrir estações públicas conjugadas (telégrafos e telefonia). No mesmo período em que houve crescimento exponencial dos serviços telegráficos, também foi ampliado o 
número de estações telefônicas, passando de 12, em 1926, para 64 em 1930. Nos serviços privados de concessões municipais, em 1917, nas cidades de Florianópolis, Joinville, Itajaí e Blumenau, havia 428 assinantes de linha telefônica; em 1926, já eram 1.097 assinantes (REPARTIÇÃO GERAL DOS TELÉGRAFOS, 1916-1926). A expectativa era de que nas décadas seguintes esse serviço cresceria de forma contínua, substituindo os telégrafos.

Anunciado o fim da telegrafia elétrica, o serviço de radiotelegrafia sem fio também começou a se proliferar no Brasil. Inventado em 1896 pelo italiano Guilherme Marconi, a primeira estação de radiotelegrafia no Brasil foi inaugurada, em 1902, no estado do Pará e, em 1904, chegou ao Rio de Janeiro (BHERING, 1914). Em Santa Catarina, a primeira antena a ser instalada foi na Lagoa da Conceição, em Florianópolis, em 1912. Ao longo dos anos de 1920, foram construídas as estações de Porto União, Blumenau, Lages, São Francisco e Dionísio Cerqueira (REPARTIÇÃO GERAL DOS TELÉGRAFOS, 1931; SANTA CATARINA, 1915). Em 1917, por meio do Decreto ${ }^{\circ}$ 3.296, de 10 de julho, os serviços de radiotelegrafia e radiotelefonia foram declarados de competência exclusiva do Estado. Obedecendo a mesma lógica das linhas postais e telegráficas, a formação de um sistema de radiotelegrafia cobriria todo o território catarinense. Era o Estado acompanhando a modernização dos meios de comunicação para melhor se adensar no território.

Diante das novas tecnologias de comunicações (telefone e radiotelegrafia), qual seria a melhor opção para se investir? Valeria a pena insistir na ampliação dos serviços telegráficos? Telefonia e radiotelegrafia eram as novas camadas geoeconômicas que se combinariam com as linhas postais e telegráficas. O sistema regional de economia ficava cada vez mais complexo.

\section{Referências}

BRANDÃO, C. A. Território e desenvolvimento: as múltiplas escalas entre o local e o global. Campinas: Editora da Unicamp, 2007.

BHERING, F. A radiotelegrafia no Brasil: elementos históricos. Rio de Janeiro: Imprensa Nacional, 1914.

CABRAL, O. R. História de Santa Catarina. Florianópolis: Lunardelli, 1994.

CANO, W. Raízes da concentração industrial em São Paulo. São Paulo: Hucitec, 1990.

CARDOSO DE MELLO, J. M. Capitalismo tardio: contribuição à revisão crítica da formação e desenvolvimento da economia brasileira. São Paulo: Brasiliense, 1988.

FURTADO, C. Formação econômica do Brasil. São Paulo: Editora Nacional, 1989. 
GOULARTI FILHO, A. Formação econômica de Santa Catarina. Florianópolis: Editora da UFSC, 2007.

GOULARTI FILHO, A. Portos, ferrovias e navegação em Santa Catarina. Florianópolis: Editora da UFSC, 2013.

LIST, G. F. Sistema nacional de economia política. São Paulo: Nova Cultural, 1986.

NETTO, F. F. 150 anos de transportes no Brasil 1822-1972. Brasília: Ministério dos Transportes, 1974.

PRADO JÚNIOR, C. Formação do Brasil contemporâneo. São Paulo: Brasiliense, 1996.

REPARTIÇÃO GERAL DOS TELÉGRAFOS. Relatórios da Repartição Geral dos Telégrafos ao Ministério da Agricultura, Comércio e Obras Públicas apresentado a Assembleia Geral Legislativa. Rio de Janeiro, 1860-1888 (Série Completa). Disponível em: http://www-apps.crl.edu/ brazil/ministerial/agricultura. Acesso em: jun. 2015.

REPARTIÇÃO GERAL DOS TELÉGRAFOS. Relatórios da Repartição Geral dos Telégrafos apresentado ao Ministério da Indústria, Viação e Obras Públicas. Rio de Janeiro: Imprensa Nacional, 1897-1931. (Série Completa)

REPARTIÇÃO GERAL DOS TELÉGRAFOS. Memória histórica. Rio de Janeiro: Ministério da Viação e Obras Públicas, 1908.

REPARTIÇÃO GERAL DOS TELÉGRAFOS. Sinopse do telegrafo no Brasil. Rio de Janeiro: Ministério da Viação e Obras Públicas, 1922.

SANTA CATARINA. Leis e resoluções da província de Santa Catarina de 1888. Desterro: Tipografia do Conservador, 1888.

SANTA CATARINA. Relatório da Secretaria dos Negócios do Estado apresentado pelo secretário Gustavo Lebon Régis ao governador Vidal José de Oliveira Ramos. Florianópolis: Tipografia doa Livraria Central, 1914.

SANTA CATARINA. Relatório da Secretaria dos Negócios do Estado apresentado pelo secretário Fúlvio Aducci ao governador Felipe Schmidt. Florianópolis: Tipografia do Estado, 1915.

SANTOS, M. Metamorfose do espaço habitado. São Paulo: Edusp, 2012. 


\section{Anexo A - Mapas da Expansão da Rede de Telégrafos em Santa Catarina}

(1867-1930)

Figura 1 - Linhas de telégrafo em Santa Catarina em 1867

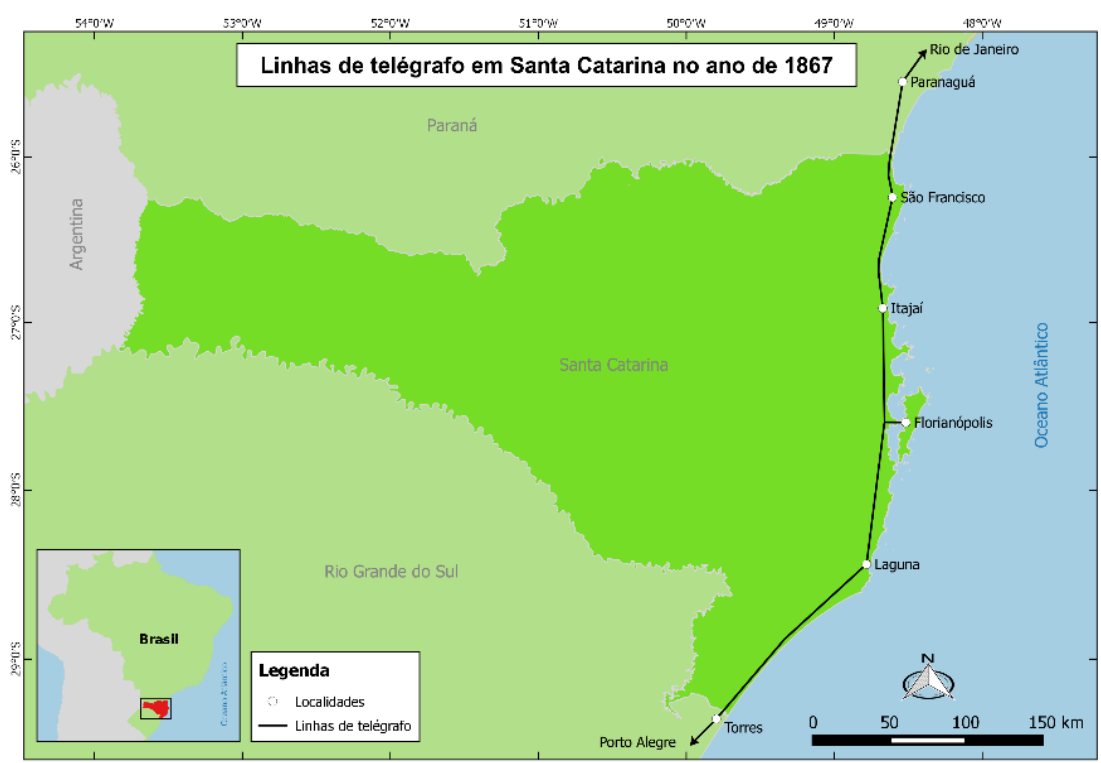

Fonte: Do autor*.

Elaborado por Ricardo Alves Colonetti. 
Figura 2 - Linhas de telégrafo em Santa Catarina em 1890

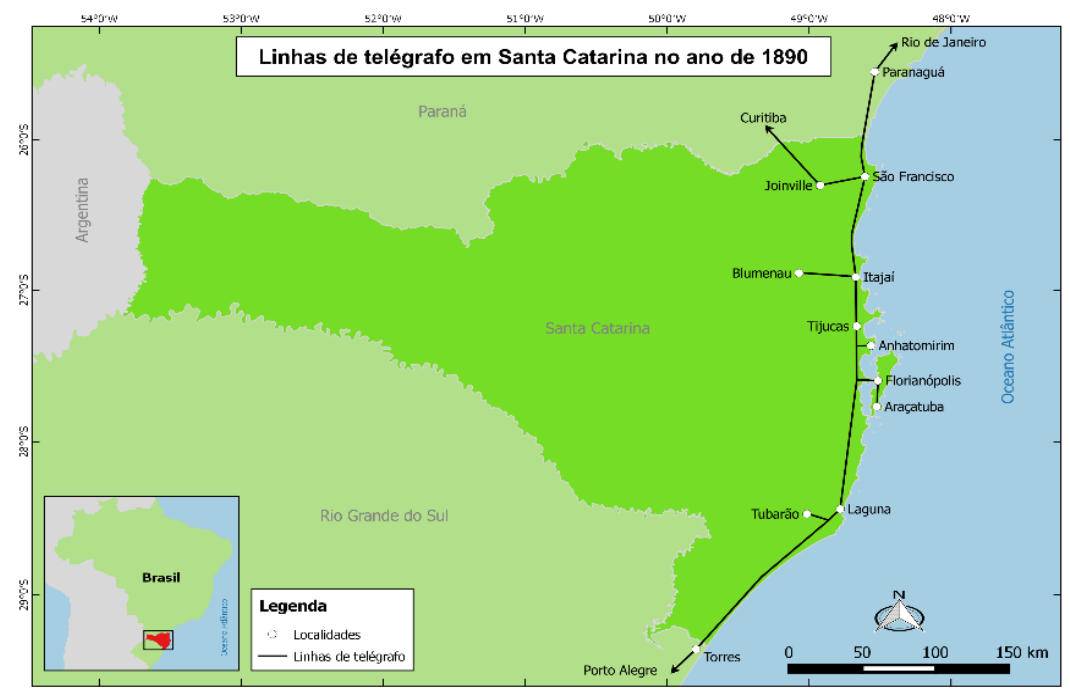

Fonte: Do autor*.

Figura 3 - Linhas de telégrafo em Santa Catarina em 1900

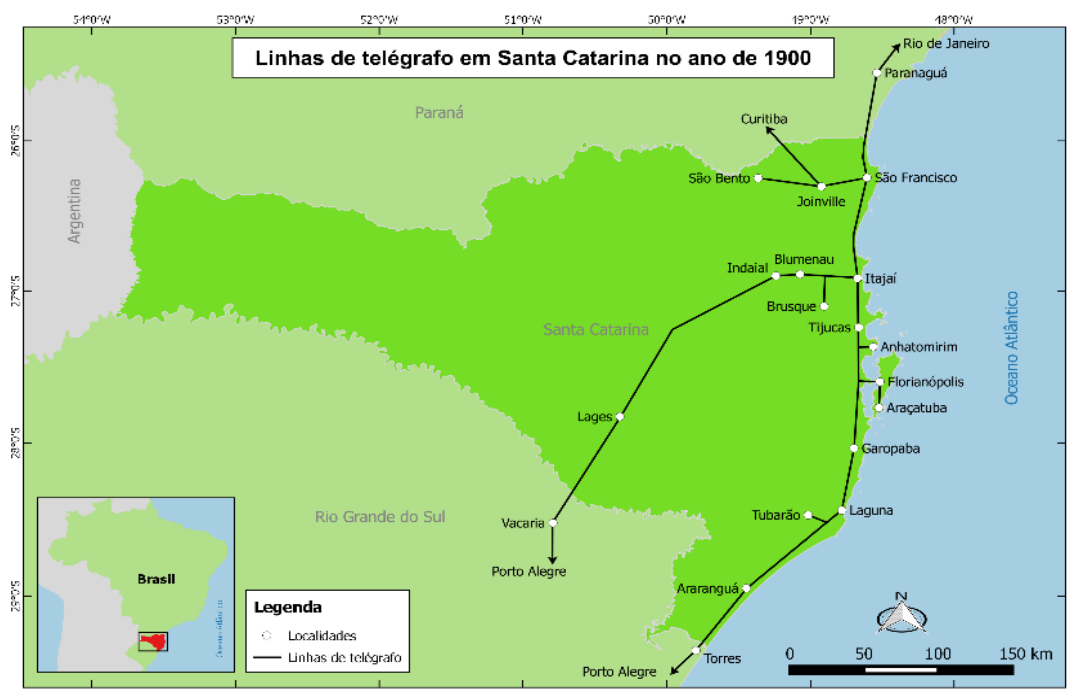

Fonte: Do autor*.

* Elaborado por Ricardo Alves Colonetti. 
Figura 4 - Linhas de telégrafo em Santa Catarina em 1907

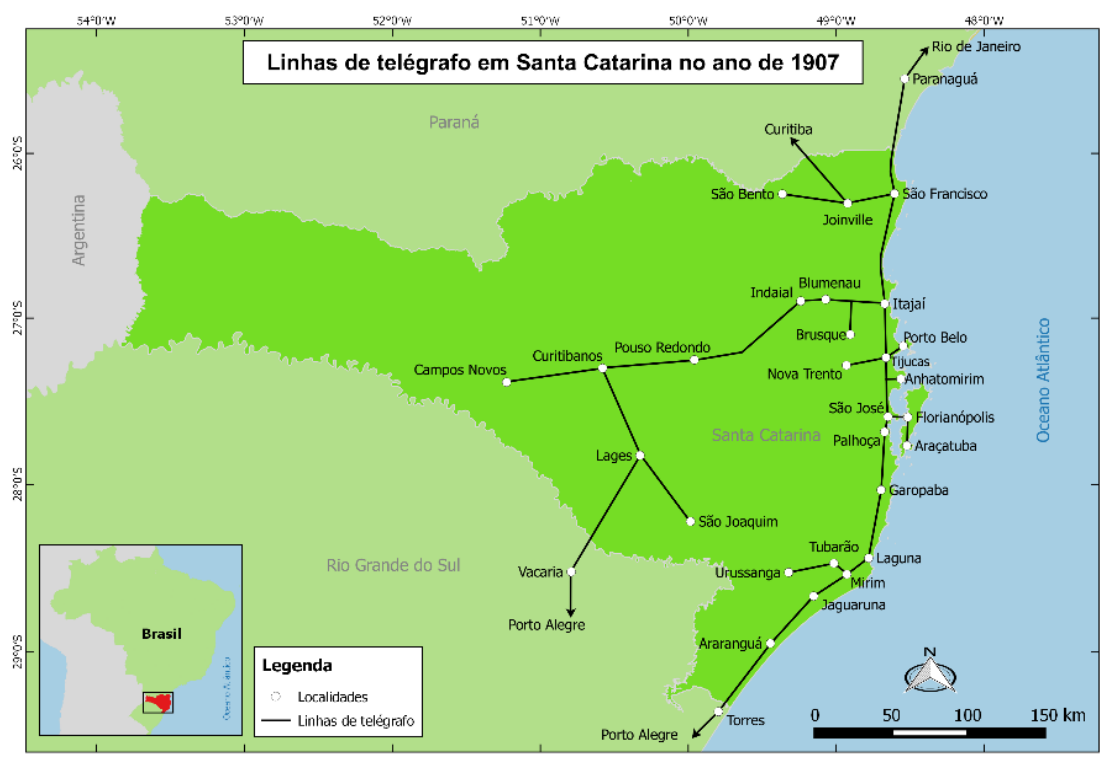

Fonte: Do autor*.

Figura 5 - Linhas de telégrafo em Santa Catarina em 1924

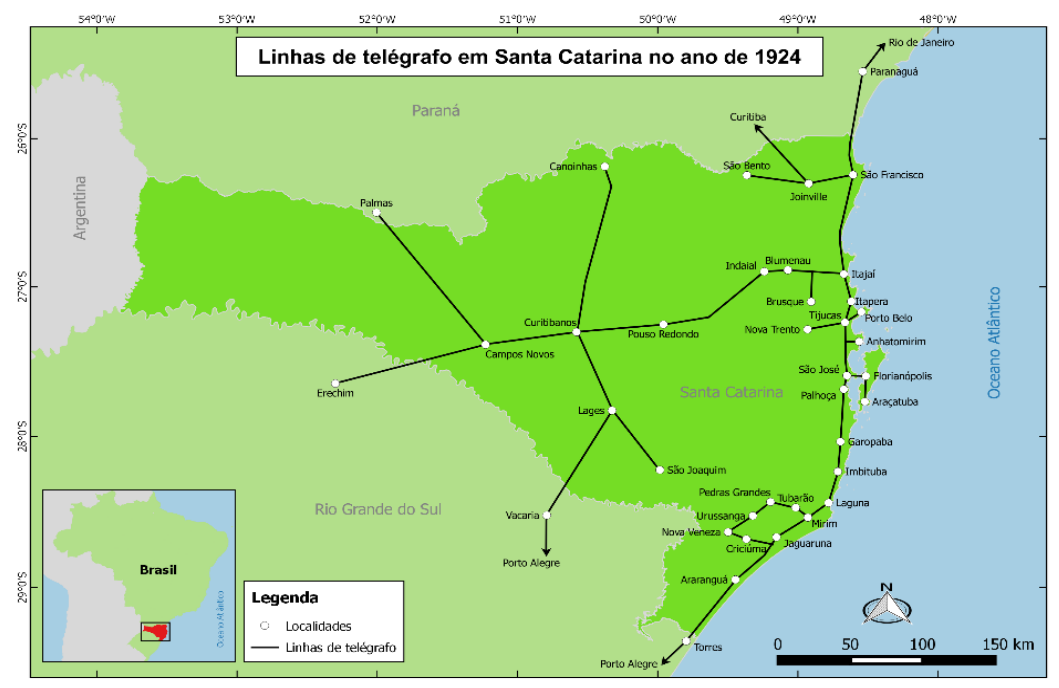

Fonte: Do autor*.

* Elaborado por Ricardo Alves Colonetti. 
Figura 6 - Linhas de telégrafo em Santa Catarina em 1930

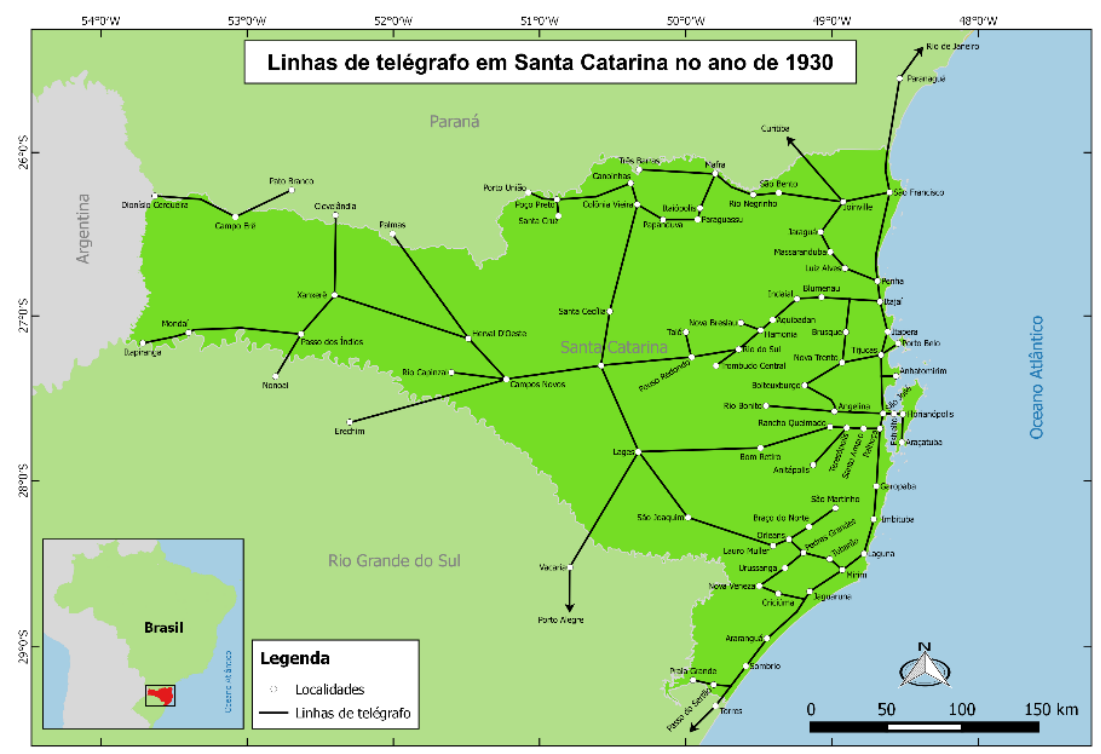

Fonte: Do autor*.

Recebido em: 30/11/2018.

Aceito em: 06/04/2019.

\section{(cc) BY}

Este é um artigo de acesso aberto distribuído sob os termos da Creative Commons Attribution CC-BY 4.0, que permite uso irrestrito, distribuição e reprodução em qualquer meio, desde que o trabalho original seja devidamente citado.

* $\quad$ Elaborado por Ricardo Alves Colonetti. 